\title{
Labor Standards in the E U-South Korea Free Trade Agreement
}

\author{
Pushing Labor Standards into Global Trade Law?
}

Giovanni Gruni

Assistant Professor, Europa Institute, Leiden Law School, Netherlands

g.gruni@law.leidenuniv.nl, @giovannigruni

\begin{abstract}
The European Union (EU) includes clauses on labor rights in free trade agreements with partner countries. One of these clauses was added to the Free Trade Agreement between the EU and South Korea. This article looks at the clause as an attempt of the EU to include labor rights in international trade law. The argument of the article is that the labor clause does include several innovative features which entrench the presence of labor law in international trade agreements. However, the clause remains mainly about political cooperation and struggles to define enforceable legal obligations on states. This is so because of the exceptions in the first part of the clause, the vagueness of the labor rights obligations and the lack of an enforcement mechanism.
\end{abstract}

\section{Keywords}

labor rights - free trade agreements - WTO - ILO - sustainable development

\section{Introduction}

The history of European labor law had a starting point when the European Community was mainly an economic organization with no labor legislation and a progressive evolution with certain labor rights sifting into the system through successive treaty reforms and secondary legislation. ${ }^{1}$ This took us to

1 For a summary of the evolution of labor law in the law of the European Union, see C Barnard, EU Employment Law (Oxford University Press, 2012). 
the system we have today where a complex body of supranational labor legislation is included in the primary and secondary law of the European Union (EU). A similar process might be happening in international trade law, an area of legislation which developed outside the international framework of human rights and labor protection. The EU is tackling this through an external policy aiming at including labor rights clauses in free trade agreements permitted by the law of the World Trade Organization (WTO). This article looks at the labor clause of the free trade agreement between the EU and South Korea, from the perspective of the protection of labor rights as contained in the Conventions of the International Labor Organization (ILO). The article takes the position that the free trade agreement between the EU and South Korea innovates if compared to the што framework linking international trade law with labor protection through references to ILo Conventions and several mechanisms of promotion of labor standards. The clause, however, remains mainly a device for political cooperation rather than legal enforcement. I maintain that labor rights could be given a more prominent role in the design of the free trade agreement extending the general dispute settlement mechanism of the treaty to the labor clause or designing a system where private parties can bring actions against States for failure to uphold labor rights.

This article is divided into six sections. The second section provides an overview of the state of the art of the relation between international trade law and international labor law. It highlights a strong separation between the two areas of legislation with international trade law being endowed with stronger enforcement mechanisms. The third section presents the main aspects of the external policy of the EU aiming to the inclusion of labor rights in free trade agreements with partner countries. This policy started mainly as a reference to the ILO agenda but then was merged into the external sustainable development policy of the EU. The fourth section delves into the labor clause of the free trade agreements between the EU and South Korea highlighting its substantive and procedural elements. The fifth section identifies three areas where the clause innovates the wTO model through extensive references to ILO Conventions, institutional design and the creation of a permanent mechanism of cooperation. The sixth section claims that notwithstanding the innovative elements of the clause the device remains mainly an instrument of political cooperation lacking legal obligations and with no enforcement mechanism. From these observations section seven maintains that labor protection could be improved extending to the ILO Conventions the general state to state dispute settlement of the free trade agreement which now applies only to trade law and intellectual property rights. As a more effective alternative free trade agreements could include a procedure where private parties can bring 
actions against States for failure to protect labor rights. This mechanism could be designed taking inspiration from the legal devices existing in the field of investment protection and which the European Commission wants to include in other EU FTAS where private investors can start actions against States to protect a set of economic rights listed in the free trade agreement.

\section{Labor Rights in International Trade Law: The State of the Art}

International trade law is the body of norms regulating transnational trade between countries and is the area of international legislation which is the most influential on the development of economic globalization. ${ }^{2}$ International trade law developed since the late 40 s and flourished trade round after trade round becoming an extensive section of public international law binding 164 countries, including the $\mathrm{EU}$, and covering a wide area of legislation from international trade of goods and services to other aspects such as non-tariff barriers and intellectual property.

The history of international trade law has been since its very beginning one of complete isolation from the international labor framework and human rights law in general. ${ }^{3}$ In 1947, the General Agreement on Tariffs and Trade (GATT) became the cornerstone of international trade law without including any references to the ILO, the United Nations or to any other labor or human rights treaties. Since that time successive trade negotiations brought to the conclusions of additional trade treaties in an institutional context, the one of "rounds" of negotiations where no institutional mechanism was in place to take into account ex ante or ex post pre-existing international labor legislation. Through these successive rounds international trade law evolved from the GATT, an agreement limited to tariffs on goods and to a few other issues, to trade in services and then to many other fields such as intellectual property, investment protection, non-tariff barriers and sanitary and phytosanitary instruments. In 1995, a turning point in the history of international trade law was the creation of the wто and of the Appellate Body, a judicial mechanism ensuring the enforcement of the GATT, the General Agreement on Trade in Services (GATS) and all other wT O covered agreements. The Appellate Body will then make history as one of the most effective international courts

2 For an introduction to global trade law, see P Van den Bossche, The Law and Policy of the World Trade Organization (Cambridge University Press, 2013).

3 E-U Petersmann, The WTO Constitution and Human Rights, 3 Journal of International Economic Law (2000) 19. 
endowed with specific procedures to assure the respect of its judgments which are named Reports. ${ }^{4}$

Along the way, labor rights never found an entry point into the system. In April 1994, at signing of the Marrakesh Agreement which created the wTO, most of the Ministers present expressed a view on the topic but it was concluded that there was no agreement on the issue. At the first wTo Ministerial Conference in Singapore in 1996, a non-binding Declaration was issued recognizing the commitment of WTO Members to internationally recognized labor rights and stating a positive link between the liberalization of international trade through the WTO action and the promotion of labor rights. Again, in 1999 at the што Ministerial in Seattle the issue was taken into consideration but the proposal for the inclusion of a labor clause in the wTO by the United States was firmly rejected by some of the Members. In particular, the idea that trade sanctions could be used to enforce labor rights appeared politically unfeasible. After the Seattle Ministerial Meeting it was widely accepted that global trade law and labor rights should be on separate tracks and that the ILO should remain the center of international labor protection. This situation favored several attempts of informal cooperation between the wто and the ILO such as the publication of common reports. ${ }^{5}$ Today this remains the only form of explicit inclusion of labor instances in the WTO system, the ILO does not have observer status in the WTO and the ILO Director General is not invited to WTO Ministerial conferences.

International trade law does not evolve only at multilateral level. Article XXIV of the GatT and Article 5 of the Gats allow the Members of the wTo to conclude side agreements deepening economic integration and trade liberalization through the creation of customs unions and free trade areas. ${ }^{6}$ Along the years the Members of the wTo concluded around 300 free trade agreements and customs unions including a wide range of economic regulation. These agreements have been the object of increasing attention after the last Round of multilateral negotiations, the Doha Round, reached a stalemate. ${ }^{7}$ The

$4 \mathrm{~J}$ Pauwelyn, Enforcement and Countermeasures in the WTO: Rules are Rules-Toward a More Collective Approach, 94(2) American Journal of International Law (2000) 335.

5 M Jansen and E Lee, Trade and Employment Challenges for Policy Research (wTO, 2007).

6 P Hilpold, Regional Integration According to Article XXIV GATT - Between Law and Politics, 1 Max Planck Yearbook of United Nations Law Online (2003) 219; K Chase, Multilateralism compromised: the mysterious origins of GATT Article XXIV 5 World Trade Review (2006) 1; L Bartels and F Ortino (Eds.), Regional Trade Agreements and the WTO Legal System (Oxford University Press, 2006).

7 D A Gantz, Liberalizing International Trade after Doha: Multilateral, Plurilateral, Regional and Unilateral Initiatives (Cambridge University Press, 2013). 
EU, in particular, designed since 2005 a wide strategy to conclude free trade agreements outside the WTO framework with more than 100 trade partners. This strategy has the potential to reshape international trade law making free trade agreements the main instrument of development of this area of legislation at a time when the WTO seems incapable of producing new legislation. ${ }^{8}$

The relation between free trade agreements and labor rights is more complex than the multilateral wTO framework. Numerous free trade agreements concluded by the EU and the United States contain references to international labor instruments and attempt to bridge the existing global gap between trade law and labor law through specific labor clauses added to the free trade agreement or through dedicated side agreements. ${ }^{9}$ In the last two decades labor clauses in free trade agreements took different forms from mere declarations of intent to binding obligations supported, in rare cases, by an enforcement mechanism. This article concentrates on the labor clause of the free trade agreement between the EU and South Korea and is the first of a new generation of agreements between the EU and its partners. The article will show that the clause addresses some of the weaknesses of the multilateral framework but remains mainly based on political cooperation rather than binding legal commitments. Before entering in the details of the clause the next section will

8 European Commission, "Report on progress achieved on the Global Europe strategy, 20062010" (Staff working document) SEC(2010) 1268/2 final; European Commission, "Trade as a driver of prosperity" (Staff Working Document) SEC(2010) 1268 final; European Commission, "Global Europe: Competing in the World" (Communication) $\sec (2006) 567$ final.

9 For a comprehensive analysis of existing international law, see L Bartels, 'Social issues: labour, environment and human rights' in S Lester, B Mercurio and L Bartels, Bilateral and Regional Trade Agreements (Oxford University Press, 2016); L Bartels, 'The Eu's approach to social standards and the TTIP' in S Khorana (Ed.), The Transatlantic Trade and Investment Partnership (TTIP) Negotiations between the EU and the USA (СIDов, 2015); L Bartels, International economic law and human rights: friends, enemies or frienemies? 7 Yearbook of European Law (2016) 485; L Bartels Human rights and sustainable development obligations in EU Free Trade Agreements, 40 Legal Issues of Economic Integration (2013) 297. On the United States practice and in particular on the labor clause of the North American Free Trade Agreement (NAFTA), see S Dewan and L Ronconi, 'U.S. Free Trade Agreements and Enforcement of labor law in Latin America' ID в Working Paper No. IDB-WP-543; M Fuentes Muniz, The NAFTA side accord in Mexico and its repercussions on workers, 10 Connecticut Journal of International Law (1994) 379; S M Spracker and G J Mertz, Labor issues under the NAFTA: options in the wake of the agreement, 27 The International Lawyer (1993) 737; M J Bolle, 'Overview of labor enforcement issues in free trade agreements' (CRS Report RS22823) Congressional Research Service; F Duina, 'Beyond free trade: accounting for labor and environmental standards in NAFTA', in T A Borzel et al. (Eds.), Governance Transfer by Regional Organizations (Palgrave Macmillan, 2015). 
introduce the external policy of the Eu aiming at the inclusion of labor rights in international trade treaties.

\section{The EU Strategy to Push Labor Rights into International Trade Law}

Since the late nineties and the intensification of economic globalization academic literature has detected an external policy of the EU dedicated to the promotion of labor rights through the conclusion of international treaties and other instruments of external action. It is in this context that the EU developed a strategy to push labor rights in international trade treaties first through labor rights clauses and then through the catch-all concept of sustainable development. This section briefly presents the evolution of this attempt from the late nineties to the more recent inclusion of labor rights in the concept of sustainable development. It is in the context of this policy that the EU pushed for the inclusion of a labor rights clause in the free trade agreement between the $\mathrm{EU}$ and South Korea.

In 1996, Catherine Barnard was already speaking of a "Community external social policy" which was based on some of the weakest external competences of the Community and was weakened by Member States disagreement. ${ }^{10}$ Along the years this external social policy took the form of a range of instruments in different areas of EU external action. ${ }^{11}$ For instance, labor rights can be found in the instruments of cooperation with developing countries such as the Cotonou Agreement and the EU Development Fund, ${ }^{12}$ the EU is active within the ILO and its participation in International Organizations is sometimes colored by social concerns. ${ }^{13}$ References to social rights and the promotion of the

10 C Barnard, 'The External Dimension of Community Social Policy: the Ugly Duckling of External Relations', in N Emiliou and D O'Keefe (Eds.), The European Union and World Trade Law after the GATT Uruguay Round (John Wiley and Sons, 1996).

$11 \mathrm{~J}$ Orbie and L Tortell (Eds.), The European Union and the Social Dimension of Globalization (Routledge, 2008).

12 M Cremona, 'Economic and Social Rights in EU external Policy' in F Bestagno (Ed.), I diritti economici, sociali e culturali (Vita e Pensiero, 2009).

13 A Clapham and J B Martignoni, 'Are We There Yet? In Search of a Coherent EU Strategy on Labour Rights and External Trade', in V Leary and D Warner (Eds.), Social Issues and international institutions: labour rights and the EU, ILO, OECD and WTO (Martinus Nijhoff, 2006). 
EU social model can also be found in the context of the European Neighbourhood Policy. ${ }^{14}$

One of the declared aims of the Eu would be to address unilaterally the weaknesses of international labor rights protection such as the lack of enforcement of the Conventions of the ILO..$^{15}$ References to the external social action has been included in the EU Lisbon Strategy, in the renewed Lisbon Strategy and more recently in the EU 2020 Strategy and take inspiration from the ILO approach to globalization that was incorporated by the EU Commission in 2001 and 2004 through the Communications "Promoting Core Labor Standards"16 and "The Social Dimension of Globalisation."17 In these Communications, the Commission identified three main areas of action. First, the active support to the ILO agenda, promoting the ratification of ILO Labor Conventions and supporting the Decent Work Program. Second, the EU should be more generally involved in promoting a reform of the ILO that would give a greater weight to the control mechanisms. Finally, the Eu should lobby in international meetings to produce a corpus of international legislation inspired by the European standards of social protection. An example of this attitude is the recent UN Disability Convention and the numerous ILO Conventions which were inspired by EU Social Directives. ${ }^{18}$

Within this policy framework the EU developed a set of instruments to use the Common Commercial Policy to promote the ratification of ILO Conventions through mechanisms of trade conditionality and the inclusion of labor clauses in free trade agreements. The rationale of this effort is that the Eu could use its leverage on global trade to support the ratification and implementation of ILO Conventions and the inclusion of labor rights in international trade law. Since the gos references to labor rights have been present in virtually every free trade agreement the EU concluded with a partner country.

The last step in the evolution of this policy framework was the inclusion of labor rights within the idea of sustainable development and the creation of an external sustainable development policy through which the European

14 S Gstohl, 'The social dimension of EU neighbourhood policies', in J Orbie and L Tortell (Eds.), The European Union and the Social Dimension of Globalisation (Routledge, 2009).

15 C McCrudden and A C L Davies, A perspective on trade and labor rights, 3 Journal of International Economic Law (2000).

$16 \operatorname{Com}(2001) 416$ final.

17 European Commission Communication, The Social Dimension of Globalisation - the EU's policy contribution in extending benefits to all, Com (2004) 383 final.

18 R Kissack, Purusing effective multilateralism The European Union, International Organisations and the Politics of Decision Making (Palgrave, 2010). 
Commission attempts to include a set of non-trade issues in the context of trade negotiations. Sustainable development is a concept that has been present in EU law since 1997 when the Treaty of Amsterdam mentioned it as an overarching objective of EU Policies. The concept of sustainable development is very wide and comprises elements of environmental protection, public health as well as social inclusion ${ }^{19}$ and the Eu has now a Sustainable Development Strategy which is regularly reviewed and assessed. ${ }^{20}$ In this context, the European Commission started to develop the idea that sustainable development should be mainstreamed in all relevant EU policies including external trade and that the EU trade policy should equally support economic growth, social development and environmental protection. Accordingly, the 2006 Revision of the EU Sustainable Development Strategy, the Communications Trade Growth and World Affairs, ${ }^{21}$ and Trade Growth and Development ${ }^{22}$ all refer to internationally recognized labor rights. For these reasons today it is through sustainable development that international labor law is called into question during trade negotiations through the design of sustainable development clauses to be added to free trade agreements which also refer to ILO Conventions. The extent to which the EU sustainable development strategy achieves its promises is however debated with different visions emerging in academic literature and policy making. ${ }^{23}$

The rest of this article takes into account the attempt of the EU to include labor rights in the sustainable development clause of the free trade agreement

19 The legal analysis of the concept of sustainable development is beyond the purview of this article. For an overview of the concept, see M-C Cordonnier Segger and Ashfaq Khalfan, Sustainable Development Law (Oxford University Press, 2004); V Barral, Sustainable Development in International Law: Nature and Operation of an Evolutive Legal Norm, 23 European Journal of International Law (2012) 377; N Schrijver, The Evolution of Sustainable Development in International Law: Inception, Meaning and Status (Brill, 2008); oECD, Institutionalising Sustainable Development (oECD Publishing, 2007); H G RuseKhan, A Real Partnership for Development? Sustainable Development as Treaty Objective in European Economic Partnership Agreements and Beyond, 13 Journal of International Economic Law (2010) 139 .

20 Eurostat, Sustainable development in the European Union 2015 monitoring report on the EU Sustainable Development Strategy (European Union, 2015).

21 European Commission Communication, "Trade, growth and world affairs" com (2010) 612 final.

22 European Commission Communication, "Trade, growth and development" SEC (2012) 87 final.

23 See for instance the heated debate around the sustainable development clause of the CETA and TTIP free trade agreements. 
with South Korea. It will emerge that the clause includes several innovative features on political cooperation but lacks of legal obligations and of a credible enforcement mechanism.

\section{The Labor Rights Clause in the EU-South Korea Free Trade Agreement}

South Korea was identified as a priority free trade agreement in the Global Europe trade policy strategy of $2006 .{ }^{24}$ In 2007 , negotiations started and after eight rounds of talks the negotiations were completed and the agreement initialled on 15 October 2009. The Free Trade Agreement is comprehensive and builds on the WTo legal liberalization of trade in goods and services, elimination of non-tariff barriers and protection of intellectual property rights.

The Free Trade Agreement between the EU and South Korea contains a section (13) dedicated to Trade and Sustainable Development. Legally, the sustainable development clause appears as an umbrella under which the treaty lists a number of other international treaties on labor rights and environmental protection. The clause is also rich of references to global social policy instruments such as the 2006 Ministerial Declaration of the United Nations Economic and Social Council on Full Employment and Decent Work. The clause can be divided in three parts: first, a general recognition of the link between trade liberalization and labor rights, second a reference to the covered international labor law and ILo Conventions, finally an ad hoc mechanism to review the implementation of the social chapter including dedicated institutions and a dispute settlement procedure.

Firstly, the labor rights clause attempts to strike a balance between the main objective of the treaty, which is liberalizing trade between the EU and South Korea and the necessity to uphold labor standards. In the clause the parties recognize the benefit of cooperation on trade-related social and environmental issues while stating at the same time that the parties remain free to define their own levels of labor protection. The clause in fact, excludes harmonization of labor rights and opts instead for a progressive approach where the parties cooperate towards increasing levels of protection. The parties in fact keep their "right to regulate" domestic labor standards, but agree to provide for and encourage high levels of protection consistent with the international instruments referred to in the clause. Recalling the wTO Singapore Declaration,

24 European Commission Communication, "Global Europe: Competing in the World" сом (2006) final. 
the clause also states that labor rights "should not be used for protectionist purposes" and that the clause should not call into question the "comparative advantage" of the parties to the agreement. ${ }^{25}$ Moreover Article 13.3 provides that the Parties shall strive to continue to improve those laws and policies. This is not an obligation to immediately enforce the selected labor standards but rather to progressively fulfil those standards and once achieved them to keep raising the level of protection.

Secondly, after the references to the concept of sustainable development and the intention of the parties to promote social law as well as economic integration, the clause includes a list of international conventions on labor rights in Article 13.4, which have three different levels of legal commitment. With regard to the four core labor standards (freedom of association and the right to collective bargaining, elimination of forced and compulsory labor, the effective abolition of child labor and the elimination of discrimination in respect of employment and occupation) the parties commit to their respect, promotion and realization. The clause then restates the obligation of the parties to implement ILO Conventions which they have ratified and adds an obligation to make "continued and sustained efforts" towards the ratification of all "up-todate" ILO Conventions. This is a list of around ninety ILO Conventions containing numerous Conventions which have not been ratified by South Korea or EU Member States.

Finally, the clause provides for four procedures that the parties can use to cooperate towards the elevation of labor standards or ensure their enforcement. These procedures are named cooperation, institutional mechanism, government consultations and panel of experts. The treaty also creates a Committee on Trade and Sustainable Development including members of the EU Commission and of South Korean Government and Domestic Advisory Groups containing representatives of civil society advising on the implementation of the clause. Under a general cooperation clause the parties commit to open a dialogue on a list of thirteen topics listed in Annex 13. The list among other things includes cooperation on impact assessments on labor rights of the liberalization process, on trade-related aspects of the ILO agenda and on cooperation at multilateral level in the Wто and the ILO. The treaty then creates an institutional mechanism on the basis of which representatives of the parties meet regularly to discuss the implementation of the chapter in the Trade and Sustainable Development Committee which also refers to the Domestic Advisory Groups including members of labor unions, environmental organizations, business organizations as well as other relevant stakeholders. Then,

25 Article $13.2(2):$ Scope. 
under the government consultation mechanism each party has the faculty to request consultations on any matter of mutual interest arising under the sustainable development chapter, in case an agreement cannot be reached each party can request that the Committee on Trade and Sustainable Development convenes and agrees on a resolution settling the issue. As instrument of last resort, whenever the consultations fail to address the issue at stake each party can request the creation of a Panel of Experts which provides recommendations on the implementation of the labor clause. The Recommendation is then monitored by the Committee on Trade and Sustainable Development and is made available to the domestic advisory groups. The closure of the sustainable development clause is an article specifying that any matter arising under the clause shall be dealt with using the mechanisms included in the clause itself. This excludes the use of the arbitration procedure provided under Article 14 of the EU-South Korea FTA.

\section{The Innovative Elements in Comparison to wTo Law}

The sustainable development clause of the EU-South Korea Free Trade Agreement is the first to be adopted in a new generation of free trade agreements and considered by the European Commission as a model for future negotiations. Considering that WTO law barely includes any references to labor rights the mere fact that the EU-South Korea agreement includes a section on labor rights can be considered an achievement of the EU sustainable development strategy. This section highlights three elements of the clause which are particularly innovative if compared to the existing wTо framework; namely, the explicit reference to ILO Conventions, the creation of institutions to support the implementation of labor rights and the creation of a system of permanent cooperation. The rest of the article will delve into the legal shortcomings of the present approach and propose paths of reforms.

First, differently from wTo law, the EU-South Korea Free Trade Agreement refers to around one hundred ILO Conventions creating specific obligations to respect and implement the Conventions or at least to work towards their ratification. This is a rather extensive reference to ILO instruments if compared to wто law which does not refer to any international labor instrument. In this respect, the EU-South Korea free trade agreement explicitly makes a link between international trade law and international labor law bringing an extensive list of labor rights into an Article XXIV GATT free trade agreement. In addition to this wide substantive basis, Article 13.7 contains the obligation not to weaken or reduce the labor protection afforded in the laws of the parties 
to encourage trade and investment. Accordingly, the labor clause obliges the party to work together towards stronger levels of labor protection and forbids the parties from lowering the achieved protection. This should create a virtuous cycle leading to increasing protection of labor rights on both sides.

Second, the free trade agreement includes an elaborate institutional design with a specific Committee, the Trade and Sustainable Development committee, which is dedicated to the implementation of the labor and environmental element of the agreement. Moreover, the Domestic Advisory Groups comprise representatives of social partners and stakeholders who are consulted on a permanent basis and are involved in case of disputes. This involves civil society and social partners in the implementation phase of the clause and in most of the procedures which are created. Through this system representatives of civil society are given an opportunity to take part to the execution of a section of a complex free trade agreement improving participation and transparency. This mechanism could also be a learning opportunity for the stakeholders involved on the labor issues arising from the creation of a free trade area between the $\mathrm{EU}$ and an emerging global player such as South Korea. This is a major difference with the што where there is no institution on trade and labor rights and where labor unions and other stakeholders are not afforded an entry point in the institutional design when dealing with labor protection.

Finally, the EU-South Korea FTA creates permanent mechanisms of cooperation on labor issues allowing the countries involved to maintain a continuous dialogue on the link between trade liberalization and labor rights. Some of the issues identified in Annex 13, the role of multilateral institutions for instance, could develop in more intense cooperation and additional proposals to push labor rights more towards the center of global economic policies. The existence of a permanent mechanism of cooperation is per se a positive element of the agreement since it allows countries which are very different between themselves to learn from their respective experiences and design innovative solutions to increase labor protection. The treaty also allows the States involved to trigger ad hoc consultations in the Trade and Sustainable Development Committee on specific labor issues and could go as far as involving an independent panel of experts to assess any emerging contentious issues. The existence of these procedures creates a permanent laboratory where the $\mathrm{EU}$ and South Korea discuss legislation of labor and work towards addressing differences in approach. The main objective of this system is to accompany the liberalization of trade between the parties with progressive ratification of the numerous labor Conventions included in the clause which are not yet ratified by South Korea or EU Member States. This idea breaks apart from the situation existing in the Wто where it is accepted that cooperation on labor issues 
should stay outside trade law and happen in specialized agencies such as the ILO or the United Nations. Doing so the EU-South Korea free trade agreement makes a procedural step to end the separation in public international law between trade and labor allowing the parties of a trade agreement to discuss labor legislation at length whenever this might affect their trade relation.

For the reasons above in the EU-South Korea free trade agreement we can identify an effort by the negotiating parties to include explicit references to labor rights and to the policies of the ILO. Doing so the EU-South Korea free trade agreement distances itself from existing multilateral trade law which has so far avoided legal interactions with the protection of labor. However, as the next section highlights, the labor clause also has numerous weaknesses.

\section{Legal Shortcomings of the Labor Clause}

The previous section highlighted several innovative elements of the labor clause of the EU-South Korea Free Trade Agreement. This section flags three fundamental weaknesses of the clause which have the potential of undermining the declared objective of ensuring progressive labor protection together with trade liberalization between the parties. These shortcomings are the theoretical subjection of labor rights to trade liberalization, the vagueness of labor rights obligations and the absence of an enforcement mechanism.

First, the clause has several articles which appear to have the role of weakening the binding value of the rest of the text. These are the parts of the clause defining the "right to regulate" while declaring the agreement of the parties to embark on a process to progressively raise labor standards. These articles clarify that the clause is not about harmonizing labor standards, that labor rights should not get into the way of the process of liberalization and that States remain free to define their level of labor protection. These general articles appear to address the issue of the relation between trade and labor giving a clear priority of the first over the second and dismissing any possibility of a conflict between labor protection and liberalization of the trade in goods and services. In case of a conflict between any section of the free trade agreement and one of the ILO Conventions listed in the sustainable development clause, the treaty seems to accept that the economic clause should be given a priority over labor rights. These introductory paragraphs go as far as defining a right of the state to regulate its own labor standards independently from the labor obligations of the free trade agreement. Accordingly, from the outset the clause reveals the intention to offer a wide leeway to the parties of the agreement to regulate their labor legislation even disregarding the binding references to the 
ILO Conventions. This makes the theoretical premises of the clause unclear. On the one hand, the labor rights clause should support the inclusion of international labor obligations in the domestic legal systems of the EU and South Korea; on the other hand, it appears to allow States to fail to do so especially when a labor right can be considered a protectionist device.

Second, the treaty sets three different levels of obligations with regard to different ILO Conventions. When referring to the eight core labor Conventions, States have an obligation to ratify and implement and there is no doubt that in principle the countries involved would violate the agreement whenever they fail to respect the obligations emerging from these instruments. This is particularly relevant for South Korea which has not ratified four core ILO Conventions on freedom of association, collective bargaining and forced labor. Both conventions are crucial to guarantee transparent participation by trade unions to the Domestic Advisory Group which is one of the important novelties of the agreement. With regard to Conventions which the States involved have ratified, there is an obligation to proceed with implementation which does not add anything to obligations already falling on States under public international law except the fact that also this obligation can be the object of the cooperation procedures included in the Free Trade Agreement. Then, with regard to the rest of ILO up-to-date Conventions the parties accepted only an obligation of working towards their ratification. In any event, this obligation appears empty of specific legal duties if looked at in the light of the premise that countries remain free to determine their own levels of protection. The function of this clause seems rather to define a key area of political cooperation in the Trade and Sustainable Development Committee. To what extent this will be fulfilled will depend on the capacity of interested parties to push certain issues in the agenda, on political bargaining and on cross bargaining between labor issues and other purely economic issues that might arise in the relation between the EU and South Korea. To sum-up, clear legal obligations to respect ILO Conventions emerge only with regard to the eight core Conventions whereas the other ILO Conventions mentioned in the FTAs will be the object of political cooperation and do not appear to be designed to be legally binding.

Third, the labor rights clause is excluded from the general state-to-state dispute settlement mechanism which means that it is unenforceable in case of non-compliance. Article 14 of the Free Trade Agreement in fact designs an articulated arbitration mechanism which can be used in case one of the parties does not respect the obligations emerging from the treaty. This mechanism includes several stages which start from consultations and move to an arbitration committee issuing a binding award which can be enforced through procedures which can result in compensation, suspension of the agreement 
or increment of tariff rates to the level applied to other wTо members. These retaliatory measures are similar to the measures already existing under WTO law and proved to have a good record of effectiveness. Only a few sections of the Free Trade Agreement are excluded from this kind of enforcement and these include the entire labor clause. This decision makes the obligations to ratify and respect core labor Conventions not enforceable under a treaty procedure and subject only to the cooperation and institutional mechanisms or as extrema ratio to the appointment of a committee of experts delivering an unbinding resolution. Since other substantive sections of the agreement such as intellectual property rights are subject to the treaty dispute settlement system the EU-South Korea free trade agreement perseverates in providing weaker enforcement to labor rights when compared to trade norms or economic regulation. This problem is represented at multilateral level with the presence of a strong international court in the WTO, the Appellate Body, in the absence of effective enforcement of labor Conventions in the ILO. The EUSouth Korea FTA does not detach itself from this situation and makes a clear decision towards enforcement of trade clauses and against enforcement of labor standards.

Finally, the empirical evidence available on the existing practice on labor standards on the EU-South Korea FTA suggests that the system in place is unable to impose the respect of core labor obligations without autonomous consent of the state party which is in breach of such obligations. In fact, even if the agreement includes a clear obligation to ratify and implement core labor Conventions, South Korea, five years from the entry into force of the treaty, has not ratified Conventions 87 on Freedom of Association, Convention 98 on the Right to Organize and Conventions 29 and 105 on the abolition of forced labor. ${ }^{26}$ Under the EU-South Korea FTA the EU Commission started a dialogue on the issue which at the moment has not resulted in any additional ratification on the Korean side. ${ }^{27}$ This is so even if the implementation of the economic sec-

$26 \quad$ ILO, Normlex Database.

27 The diplomatic dialogue happening under the EU-South Korea FTA produced an unbinding declaration by South Korea that it will speed up efforts to ratify all core ILO Conventions. See European Commission, News, "South Korea to improve labor rights under EU-Korea Free Trade Agreement" available at http://ec.europa.eu/social/main. jsp?langId=en\&catId=82\&newsId=2320\&furtherNews=yes. A 2016 Report of the United Nations Special Rapporteur on the Freedom of Association still highlights lacks of implementation in South Korea of the international framework for the protection of labor unions, see United Nations Human Rights Council, Report of the Special Rapporteur on the rights to freedom of peaceful assembly and of association on his mission to the Republic of Korea, A/HRC/32/36/Add.2. 
tions of the FTA is well underway. ${ }^{28}$ In fact, the present stalemate suggests that even if the instruments of cooperation on labor standards keep an ongoing dialogue on the issue, at the same time their existence assures that the state party is not under immediate threat of losing trade preferences if in breach of the labor section of the free trade agreement. In addition, the situation at hand manifests the separation between the process of trade liberalization and clause upholding labor standards. In fact, the free trade elements of the EUSouth Korea FTA are in force and implemented even in the absence of compliance with the fundamental obligation of the labor section of the treaty.

In conclusion, the labor clause of the EU-South Korea Free Trade Agreement fails to go beyond the creation of an institutional framework to discuss labor rights issues on the basis of a wide agenda referring to ILO Conventions. The present system lacks binding obligations to uphold labor rights and a convincing enforcement mechanism. Accordingly, the clause fails to give labor rights the same legal status as the trade and intellectual property sections of the agreement. Notably, the drafters of the EU-South Korea Free Trade Agreement opted for a model of enforcement of labor obligations which is weaker than what already exists in international practice. For instance, the North American Free Trade Agreement (NAFTA) entered into force in 1994, namely fifteen years before the EU-South Korea FTA, already included a procedure allowing private parties to file complaints for violations of the labor standards included in the agreement. ${ }^{29}$ On the contrary, the EU-South Korea FTA does not even go as far as providing for a complete state-to-state dispute settlement mechanism. The legal weaknesses identified above replicate some of the shortcomings of the WTO system so that the EU-South Korea FTA does not fully succeed in upholding labor protection in the countries involved.

\section{Taking Labor Protection to the Next Level: State to State and Private Party to State Dispute Settlement}

The section above identified three dimensions of the labor clause of the EU-South Korea Free Trade Agreement which have the result that labor rights

28 See European Commission, Press Release, "Trade boosted by five years of EU-Korea Free Trade Agreement" available at http://europa.eu/rapid/press-release_IP-16-2356_en.htm.

29 See S Hertzenberg, Calling Maggie's bluff: the NAFTA Labor Agreement and the development of an alternative to Neoliberalism, 28 Canadian-American Public Policy (1996); L A Compa, The first NAFTA labor cases: a new international labor rights regime takes shape, 3 United States - Mexico Law Journal (1995) 159. 
are afforded weaker protection than most of the trade regulation included in the treaty. This section proposes two possible directions that could be taken to strengthen the labor dimension of EU free trade agreements providing labor rights a similar legal status to what is given to trade law and intellectual property rights. One option would be to extend to the labor clause the general dispute settlement of the free trade agreement and the other to include a system allowing private parties to bring actions in case of violations of labor rights as it happens in free trade agreements including an element on investment protection. ${ }^{30}$

As shown above, in case of a violation of one of the ILo Conventions mentioned in the free trade agreements, the only viable option for the private party affected would be to lobby its own government to start one of the mechanisms of political cooperation provided by the clause. In any case, in the absence of domestic protection, the treaty does not provide any additional legal defense ensuring the protection of the individual from violations of their labor rights also if the violation concerns core labor standards. At the very best, the private party could attempt to push their government towards requesting the creation of committee of experts addressing the labor violation. However, even in a situation where the state was willing to resolve the issue, this would not go beyond diplomatic instruments and legal enforcement would be impossible. The situation would be different if the free trade agreement was allowing the parties to use the dispute settlement mechanism of Article 14 which could lead to the suspension of the agreement or to retaliatory measures against the other party. This choice would have three immediate consequences on labor rights. First, it would end a rather extreme form of legal exceptionalism against labor rights in global economic law whereby there is an evident gap between the enforcement instruments of ILO Conventions and the instruments to enforce trade law and intellectual property rights. Second, it would provide the parties to the agreement with the legal instruments to enforce core ILO Conventions in the absence of cooperation from the other party. Finally, it would provide labor rights with an effective mechanism of enforcement in case of perseverating non-compliance after the award of the arbitral tribunal since the lack of respect of the ILO Convention could go as far as temporarily suspending the free trade agreement or setting up trade retaliatory measures against the other country.

30 On procedural enforcement of the rights of foreign investors in EU FTAs, see F Baetens, The European Union's proposed investment court system: addressing criticisms of investorstate arbitration while raising new challenges 4 Legal Issues of Economic Integration (2016) 367 . 
Even with state-to-state dispute settlement available to protect labor rights under the free trade agreement, the private party would not be allowed to use any procedures in the absence of cooperation from its own government which would have the responsibility to bring a legal action against the third state for violations of one of the ILO Conventions included in the free trade agreement. This is an unlikely scenario since countries are notably reticent to start international law suits against other States especially when this concerns sensitive issues such as human rights or labor protection. ${ }^{31}$ In addition, there is evidence that countries are not using the arbitration procedures available in free trade agreements even when key economic interests are at stake. ${ }^{32}$ If free trade agreements dispute settlement procedures are not used in case of violations of the core norms on liberalization of goods and services it appears unlikely that countries would start using such procedures to enforce labor rights on third parties. Accordingly, a more functional strategy would be to provide private parties with the legal instruments to challenge the violation of the labor right committed by the state. How this could be done is open to different views, but a possible direction could be the use of an enforcement mechanism similar to the one the European Commission is proposing in free trade agreements including an element of investment protection. The European Commission is in fact suggesting additional enforcement in free trade agreements for a set of economic rights linked with the protection of foreign investors. In the idea of the Commission when private rights of foreign investors are violated this should lead to the availability to the foreign investor of a supranational procedure allowing them to sue the country violating such rights. This mechanism, called investor-state dispute settlement (ISDS) allows the private party to take direct action against the state and to receive an enforceable award from an investment arbitration panel or from an investment court.

This kind of enforcement mechanism is much more intrusive of state legislative prerogatives and it proved to have substantial leverage on countries which make their best efforts to avoid possible ISDs litigations against foreign

31 This bias is evident in the case law of the European Court of Human Rights where most of the cases reach the court through private actions instead of state to state action. In European Union law, in the case of infringement actions where a Member State can bring a case against another Member State in front the Court of Justice of the European Union, this happened very rarely.

32 G Marceau and J Wyatt, Dispute Settlement Regimes Intermingled: Regional Trade Agreements and the WTO, 1 Journal of International Dispute Settlement (2010) 67; ACM de Mestral, Dispute Settlement under the WTO and RTAs: an Uneasy Relationship, 12 Journal of International Economic Law (2013) 777 . 
investors. This went as far as, in some cases, to having countries looking for legal advice ex ante before passing a piece of domestic legislation in order to ensure that the law at issue does not violate the investors rights recognized by the international treaty. ${ }^{33}$ This is so because the threat of having to pay compensation for violations of substantive rights emerging from the international treaty is a powerful incentive for the state to stick to what the treaty mandates. A similar approach could be extended to the protection of labor rights under the free trade agreements concluded by the EU. A system similar to the ISDS where an individual can bring an action under the free trade agreement against a state for failure to uphold a set of ILO Conventions would ensure that private parties have a legal mechanism in their hands to guarantee the respect of the labor rights the free trade agreement provides. For instance, the private action could trigger the creation of an ad hoc tribunal of labor experts or, as an alternative, a more permanent court could be created. With regard to investment protection, the European Commission is proposing this last solution in the Transatlantic Trade and Investment Partnership, a major free trade agreement being negotiated between the EU and the United States. ${ }^{34}$

In conclusion, the $\mathrm{EU}$ could be more assertive in terms of labor protection providing the enforcement mechanisms of ILO Conventions referred to in the free trade agreements at least with the same level of enforcement given to the trade and intellectual property clauses in the treaty. This would mean extending the general state-to-state dispute settlement mechanism also to cases of violations of ILo Conventions with the consequence that this could lead to the suspension of the agreement or retaliatory measures. A step further would be the creation of a procedure allowing private parties to sue States for lack of protection of the labor rights granted by the ILO Conventions included in the sustainable development clause. This would take labor rights to the higher

33 See K Tienhaara, 'Regulatory chill and the threat of arbitration: a view from political science', in T Kyla (Ed.), Evolution in Investment Treaty Law and Arbitration (Cambridge University Press, 2011); S A Spears, The Quest for Policy Space in a New Generation of International Investment Agreements 13 Journal of International Economic Law (2010) 1037; T Voon and A Mithcell, Time to Quit? Assessing International Investment Claims against Plain Tobacco Packaging in Australia, 14 Journal of International Economic Law (2011) 515; T Meshel, Human Rights in Investor-State Arbitration: The Human Right to Water and Beyond, 6 Journal of International Dispute Settlement (2015) 277; J E Vinuales, Foreign Investment and the Environment in International Law: An Ambiguous Relationship, 80 British Yearbook of International Law (2009) 244.

34 See the "European Union, proposal for Investment Protection and Resolution of Investment Disputes" available on the official website of the European Commission. 
level of protection the European Commission is proposing to afford to investors rights in the new generation of free trade agreements it is negotiating.

\section{Conclusions}

Since the GATT era, international trade law developed separately from the international framework of human rights and labor protection. This separation between international trade law and labor rights perseverates after the creation of the WTO since any attempts to include a labor clause in the institution failed. International trade law however also develops through the conclusion of free trade agreements between wTO members which are allowed by specific clauses in the GATT and GATS. Free trade agreements, in fact, are becoming a more prominent source of legislation after attempts of negotiating new agreements in the wTо Doha Round did not produce any outcome. Accordingly, the European Commission designed a wide strategy to conclude free trade agreements with around 100 trade partners. From the policy papers of the European Commission clearly emerges an effort to add to this new generation of free trade agreements labor clauses referring to the Conventions of the ILO under the EU sustainable development agenda which was given a clear social dimension.

This article took into account the labor element of the sustainable development clause of the free trade agreement between the EU and South Korea asking to what extent it solves the separation between labor rights and international trade law. Firstly, the article maintained that the clause is innovative if compared to WTO law since it has a clear reference to ILO Conventions. It provides for dedicated institutions and embarks the parties on a long-term cooperation on labor issues. Secondly, the article found that the clause lacks legal obligations to ratify and implement the referred ILO Conventions and does not have any enforcement mechanism. Finally, the article maintained that the protection of labor rights could be improved extending the general dispute settlement mechanism to the labor clause or designing a procedure to allow private parties to sue States for failure to uphold the rights contained in the ILO Conventions. The procedure could be inspired to the mechanisms the European Commission is proposing to uphold investor's rights allowing foreign investors to bring actions against States.

From the analysis earlier, we can draw conclusions on both the EU and international trade law. With regard to the $\mathrm{EU}$, from the experience of the $\mathrm{EU}$ South Korea Free Trade Agreement emerges the clear political effort of the European Commission to build a narrative of international trade policy which 
also includes non-trade elements such as the protection of labor rights and the environment. This sustainable development strategy in the case of the EU-South Korea Free Trade Agreement produced a specific clause which is in a self-contained section of the treaty and provides for a wide substantive basis as well as dedicated institutions. This shows that the EU has the leverage in trade negotiations to push labor rights more towards the center of the global economic agenda even when negotiating with strong emerging economies. The approach used in the context of the treaty at issue however fails to provide labor rights with the same legal status as the trade part of the agreement or intellectual property rights. The sustainable development clause in fact is at the same time a device to include non-trade issues in the agreement and the legal instrument to single these issues out from the rest of the treaty avoiding the legal effects they might have had if considered equal to trade norms. In this respect, the EU sustainable development strategy appears unable to achieve the same outcome during trade negotiations as the EU common commercial policy. This shows that the trade dimension of the EU external action remains prominent across the board and that labor rights at the moment are included only to the extent they do not interact with the commercial objectives of the parties to the agreement. To what extent this outcome was sought by EU negotiators remains an open question since at the moment no access is provided to the preliminary drafts of the free trade agreement. The result is however that the EU while making a statement about the inclusion of labor rights in free trade agreement also fails to address the weaknesses of labor protection of global law where the ILO is not endowed with enforcement mechanisms as effective as the WTO. In addition, it fails to provide inventive solutions to international protection of labor rights, for instance proposing ad hoc dispute settlement mechanisms as it does with regard to economic rights of foreign investors.

With regard to international trade law the EU-South Korea Free Trade Agreement breaks apart from the WTO framework making some steps towards the inclusion of labor rights in international trade law through binding references to ILo Conventions and dedicated institutions to address labor issues which are completely absent in the wTо. The clause remains however half way in terms of addressing the weaknesses of the present system for the reasons highlighted above. In addition, the free trade agreement resolves the tension between trade liberalization and labor protection providing a general priority to trade interests over labor rights. This choice weakens the legal value of the agreement and clearly makes the sustainable development clause more an instrument of political cooperation than an enforceable piece of international law. Accordingly, the outcome of the negotiations is an agreement which 
draws a picture where the law assists trade norms and intellectual property rights whereas labor protection depends on the diplomatic influence of the parties and their political willingness to raise labor standards. The agreement also confirms that whereas international economic law in the last two decades has been the laboratory for the experimentation of innovative mechanisms of enforcement which were sometimes unprecedented in the history of public international law, labor rights remain excluded from these developments and rely on more traditional diplomatic instruments of cooperation. 